\title{
The Effects of Controlled Drainage on N Concentration and Loss in Paddy Field
}

\author{
Bin Lu, ${ }^{1,2}$ Guangcheng Shao, ${ }^{2}$ Shuang'en Yu, ${ }^{2}$ Shiqiang $W u,{ }^{1}$ and Xinghua Xie ${ }^{1}$ \\ ${ }^{1}$ State Key Laboratory of Hydrology-Water Resources and Hydraulic Engineering, Nanjing Hydraulic Research Institute, \\ Nanjing 210029, China \\ ${ }^{2}$ Efficient Irrigation and Drainage and Environment of Agriculture Water and Soil, South Area Key Laboratory, \\ the Ministry of Education, College of Water Conservancy and Hydropower, Hohai University, Nanjing 210098, China
}

Correspondence should be addressed to Bin Lu; 370568102@qq.com

Received 13 October 2015; Accepted 21 March 2016

Academic Editor: Yuangen Yang

Copyright (C) 2016 Bin Lu et al. This is an open access article distributed under the Creative Commons Attribution License, which permits unrestricted use, distribution, and reproduction in any medium, provided the original work is properly cited.

To relieve the situation of the agricultural nonpoint pollution (NPS) in south and east China, paddy field controlled drainage (PFCD) is applied as an important and efficient approach to agricultural water management. A series of PFCD tests at four major growth stages of rice were conducted by use of 18 lysimeters. Concentration of ammonia nitrogen $\left(\mathrm{NH}_{4}{ }^{+}-\mathrm{N}\right)$ and nitrate nitrogen $\left(\mathrm{NO}_{3}{ }^{-}-\mathrm{N}\right)$ in surface and subsurface paddy water was observed. The results indicated that the concentration of $\mathrm{NH}_{4}^{+}-\mathrm{N}^{-} \mathrm{and} \mathrm{NO}_{3}^{-}$ $\mathrm{N}$ in paddy water declined with the persistence of a waterlogged condition. Compared to traditional drainage, PFCD reduced $\mathrm{N}$ loss in surface water by $95.6 \%, 78.7 \%, 59.6 \%$, and $87.4 \%$ at the stage of tillering, jointing-booting, heading-flowering, and milking, respectively. It should be noted that loads of $\mathrm{N}$ losses in surface water increased on the fourth day after waterlogging at the jointingbooting and milking stage, and surface water exhibited higher $\mathrm{N}$ concentration on the first day after waterlogging at each stage. Therefore, paddy field surface water drainage should be avoided in these periods.

\section{Introduction}

Field drainage is widely known as an essential measure to ensure that crops achieve high and steady production. However, unreasonable field irrigation and drainage management present several problems as well. For example, excess drainage leads to the mass flow of agriculture pollution into rivers and lakes. Furthermore, nitrogen $(\mathrm{N})$ and phosphorus (P) runoff and drainage from paddy fields are major sources of nonpoint source pollution (NPS) in south and east China [1-3]. In several major lakes such as Taihu Lake, Dianchi Lake, and Chaohu Lake, eutrophication has become increasingly severe [4-7]. With regard to problems of water shortage and water environment deterioration, controlled drainage $(\mathrm{CD})$ has been identified as an efficient approach to agricultural water management in humid and arid regions [8-10].

Paddy field controlled drainage (PFCD) is a highly efficient drainage pattern that uses the institution of outfall to control field water discharge and elevate the level of farm ditch, as well as achieving water saving and pollution reduction $[11,12]$. This pattern is different from the conventional pattern of paddy field drainage. Industry practice shows that paddy fields can retard and store floodwater during major flood periods. Furthermore, paddy fields not only save irrigation water and improve the utilization of rainwater but also alleviate the region pressure of flood protection [10, 11].

Controlled drainage, which is also called drainage water management (DWM), has been used for several years in North Carolina, Florida, and other locations $[9,13]$. In the controlled drainage situation, the flow lines are shallower than in the uncontrolled system, and the water table is maintained at a shallower depth by a control structure which reduces deep percolation below the root zone by reducing hydraulic gradients and increases capillary upflow as evapotranspiration depletes soil water in the root zone [8]. Numerous studies have shown that CD could reduce annual transport of total $\mathrm{N}$ in the field by $40 \%-50 \%$ and total $\mathrm{P}$ by $35 \%-$ $45 \%$ [14-17]. Annual CD could reduce approximately 30\%$60 \%$ of water volume compared with conventional drainage [18-20]. One the one hand, CD can reduce total leaching rate from less water drainage; on the other hand, the rise of 
TABLE 1: Physical and chemical characteristics of topsoil (0-30 cm layer) in lysimeters.

\begin{tabular}{lcccccccc}
\hline $\begin{array}{l}\theta_{n} \\
(\%)\end{array}$ & $\begin{array}{c}\rho_{b} \\
\left(\mathrm{~g} / \mathrm{cm}^{3}\right)\end{array}$ & $\begin{array}{c}\text { Porosity } \\
(\%)\end{array}$ & $\begin{array}{c}\mathrm{pH} \\
(-)\end{array}$ & $\begin{array}{c}\text { Organic matter } \\
(\mathrm{g} / \mathrm{kg})\end{array}$ & $\begin{array}{c}\text { Total N } \\
(\mathrm{g} / \mathrm{kg})\end{array}$ & $\begin{array}{c}\text { Available N } \\
(\mathrm{mg} / \mathrm{kg})\end{array}$ & $\begin{array}{c}\text { Total P } \\
(\mathrm{g} / \mathrm{kg})\end{array}$ & $\begin{array}{c}\text { Available P } \\
(\mathrm{mg} / \mathrm{kg})\end{array}$ \\
\hline 25.28 & 1.46 & 44.97 & 6.97 & 21.88 & 0.9048 & 27.65 & 0.32 & 12.5 \\
\hline
\end{tabular}

Note: $\theta_{n}$ and $\rho_{b}$ represent field moisture capacity and soil bulk density, respectively.

subsurface water level can prompt soil denitrification, which then decreases the concentration of nitrate nitrogen.

The PFCD technology was discovered by Chinese scholars in the 1990s, and several experimental studies and field practices have been conducted constantly in rice-planting regions. Zhang et al. [21] studied the transport and loss of nitrogen in a drainage paddy field. Luo et al. [22] and Jia et al. [23] conducted field experiments on the effects of drainage control on salt and water balance in the Yinnan irrigation district. Xiao et al. [24, 25] examined the changes in $\mathrm{N}$ and $\mathrm{P}$ of flooded paddy water systems and obtained the optimal drainage time at each stage of growth. All the results concluded that PFCD plays a significant role in water conservation and nonpoint source pollution reduction.

Two important factors for PFCD are surface water level and waterlogging duration. When the paddy surface water level is too deep or when the duration of waterlogging is too long, a waterlogged disaster can occur, which may then cause plant growth retardation and yield reduction. On the contrary, pollution reduction and water conservation cannot be achieved when waterlogging duration is too short. To achieve comprehensive benefits from environment and economic resources, we must assess surface water depth, flooding time, leakage intensity, and other factors [26, 27].

This study emphasized the environmental benefits of deliberate water resources utilization. The paper showed dynamic changes in $\mathrm{N}$ concentration in surface and subsurface paddy water, analyzed the effects of leakage intensity and $\mathrm{N}$ leaching, calculated loads of $\mathrm{N}$ losses through surface drainage, and demonstrated the effects of pollution reduction and water saving through PFCD.

\section{Materials and Methods}

2.1. Experimental Site. This study was conducted in an experimental field at water-saving and agroecological experimental plot located in Jiangning Campus of Hohai University, Jiangsu Province of China (Nanjing, latitude $31^{\circ} 57^{\prime} \mathrm{N}$, longitude $118^{\circ} 50^{\prime} \mathrm{E}, 144 \mathrm{~m}$ above sea level). The region has a subtropical humid monsoon climate zone, with an average annual evaporation of $900 \mathrm{~mm}$ and yearly average temperature of $15.7^{\circ} \mathrm{C}$, and the maximum and minimum air temperatures are $43.0^{\circ} \mathrm{C}$ and $-14.0^{\circ} \mathrm{C}$, respectively. The mean annual rainfall is $1021 \mathrm{~mm}$ of which more than $60 \%$ of precipitation falls in the rainy season and the precipitation is concentrated in May to September. The number of frost-free days is 237 per year. The temperature, precipitation, and evaporation were recorded daily by an automatic weather station (ICT, Australia) in the experimental plot.

The area has been 5 years of rice-wheat rotation system. The soil in the area is a typical permeable paddy soil. The topsoil was $0-30 \mathrm{~cm}$ in lysimeter with $\mathrm{pH}$ value of 6.97 , soil bulk density was $1.46 \mathrm{~g} / \mathrm{cm}^{3}$, soil porosity was $44.97 \%$, and field capacity was $25.28 \%$. Characteristics of topsoil are shown in Table 1. There are 32 fixed lysimeter test-pits ( 28 with closed concrete bottom, 4 without bottom) with specifications for the length $\times$ width $\times$ depth $=2.5 \mathrm{~m} \times 2 \mathrm{~m} \times 2 \mathrm{~m}$ in the exper imental field. Those lysimeters layouts were divided into two groups of 16 each. We only employed 18 of them in this research, shown in Figure 1(a). Underground gallery and drainage system are built between the two groups, and a mobile canopy is equipped on the ground.

An integrated irrigation-drainage system (IDS) was installed at the experimental field. For the irrigation system, water was supplied from an underground reservoir to every test-pit through pipelines, and the accuracy of irrigation water volume is controlled by a computer by controlling the electromagnetic flow valves (see Figures 1(a) and 1(c)). Water table was changed by raising or lowing the height of a float valve for each treatment. When the ponded water depth dropped to the lower water level, irrigation water was added with auto-irrigation system until the upper water level limit was reached. For details of water table control structures, see Figure 1 in [28]. The drainage system is located in subsurface below the ground path in the middle of the test-pits (see Figures 1(a) and 1(b)). Groundwater in the test-pits can be discharged through artificial drainage, which can control drainage time and water volume and facilitate collection of groundwater samples.

2.2. Experimental Design. The variety of rice used in the 2010 experiment was Japonica rice Yangjing 4038. To perform paddy field water level management under different flooding conditions, we designed a series of tests at the four major stages of rice growth (tillering, jointing and booting, heading and flowering, and milky stage, in such order). The paddy field water levels, rice growth stages, and controlled drainage periods are summarized in Table 2.

Eight waterlogging and controlled drainage treatments (W1-W8) and one treatment for comparison (CK) were used in the experiment, each with two reduplications. Waterlogging treatments were performed in lysimeters with a closed bottom, whereas comparative treatments were performed in lysimeters without a bottom. Two leakage rates $(2 \mathrm{~mm} / \mathrm{d}$ and $4 \mathrm{~mm} / \mathrm{d}$ ) were designed under the same flooding condition in each stage. The paddy field waterlogging process was simulated after one occurrence of intensive rainfall in different periods. The irrigation program used on comparative treatments was based on controlled irrigation, which is an irrigation program for water saving $[28,29]$.

Agricultural fertilization was conducted three times during the period of rice growth. The fertilizers applied were base 


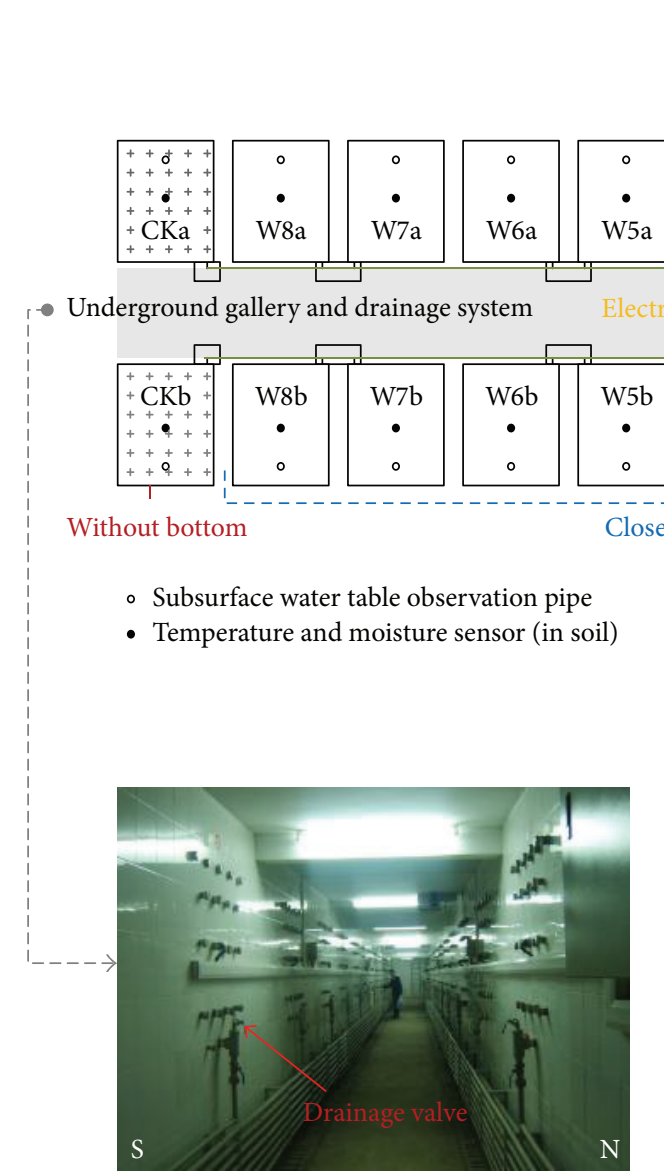

(b)

(a)

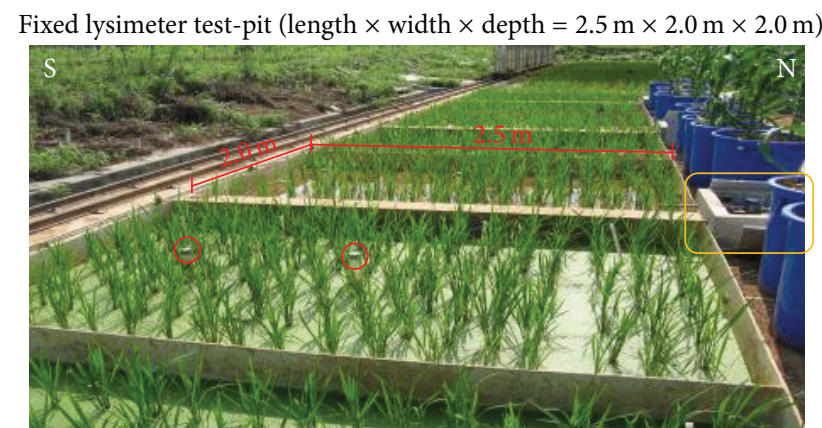

(c)

FIGURE 1: (a) Schematic diagram of irrigation-drainage system (IDS) and test-pits distribution. Water was supplied from an underground reservoir to every test-pit through pipelines. (b) Underground gallery and drainage system. (c) Lysimeter test-pits. Inside the yellow box is the electromagnetic flow valve device.

TABLE 2: Design of PFCD water level and controlled periods in 2010.

\begin{tabular}{|c|c|c|c|c|}
\hline Growth stage & Tillering stage & Jointing-booting stage & Heading-flowering stage & Milking stage \\
\hline $\begin{array}{l}\text { Growth date } \\
\text { (month/day) }\end{array}$ & Jul 05 Aug 05 & Aug 06 Aug 26 & Aug 27 Sep 09 & Sep 10 Sep 22 \\
\hline $\begin{array}{l}\text { Control date } \\
\text { (month/day) }\end{array}$ & Jul 19 Jul 28 & Aug 14 Aug 23 & Aug 30 Sep 08 & Sep 12 Sep 21 \\
\hline \multicolumn{5}{|c|}{$\begin{array}{l}\text { Surface water level or } \\
\text { subsurface water table } \\
\text { depth }(\mathrm{mm})\end{array}$} \\
\hline W1 & $120(2 \mathrm{~mm} / \mathrm{d})$ & $-300 \sim 30$ & $-300 \sim 30$ & $-300 \sim 30$ \\
\hline W2 & $120(4 \mathrm{~mm} / \mathrm{d})$ & $-300 \sim 30$ & $-300 \sim 30$ & $-300 \sim 30$ \\
\hline W3 & $-200 \sim 20$ & $250(2 \mathrm{~mm} / \mathrm{d})$ & $-300 \sim 30$ & $-300 \sim 30$ \\
\hline W4 & $-200 \sim 20$ & $250(4 \mathrm{~mm} / \mathrm{d})$ & $-300 \sim 30$ & $-300 \sim 30$ \\
\hline W5 & $-200 \sim 20$ & $-300 \sim 30$ & $250(2 \mathrm{~mm} / \mathrm{d})$ & $-300 \sim 30$ \\
\hline W6 & $-200 \sim 20$ & $-300 \sim 30$ & $250(4 \mathrm{~mm} / \mathrm{d})$ & $-300 \sim 30$ \\
\hline W7 & $-200 \sim 20$ & $-300 \sim 30$ & $-300 \sim 30$ & $250(2 \mathrm{~mm} / \mathrm{d})$ \\
\hline W8 & $-200 \sim 20$ & $-300 \sim 30$ & $-300 \sim 30$ & $250(4 \mathrm{~mm} / \mathrm{d})$ \\
\hline CK & $-200 \sim 20$ & $-300 \sim 30$ & $-300 \sim 30$ & $-300 \sim 30$ \\
\hline
\end{tabular}

Note: bold types indicate paddy field controlled drainage treatments at different stages, the left numeral is paddy water level, and the numeral in parentheses is drainage intensity under control. Minus sign represents subsurface water table depth. 

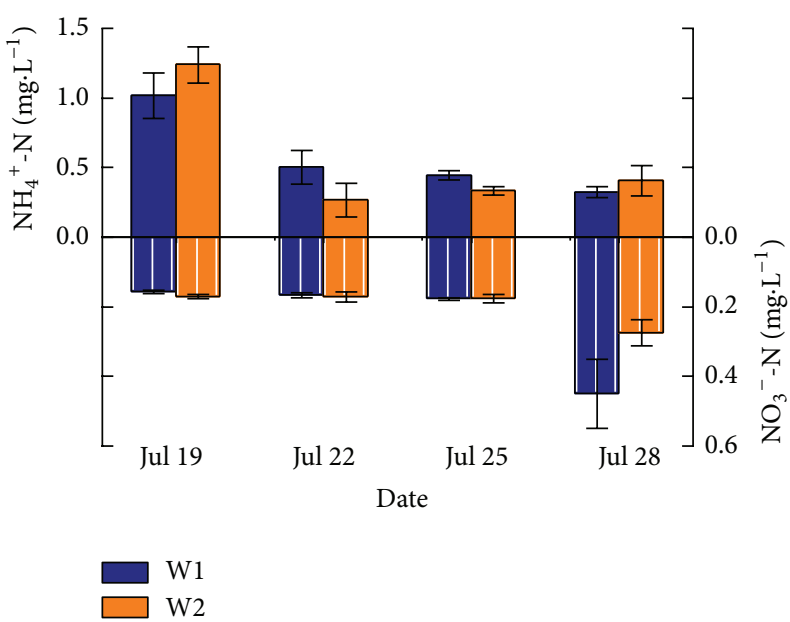

(a)

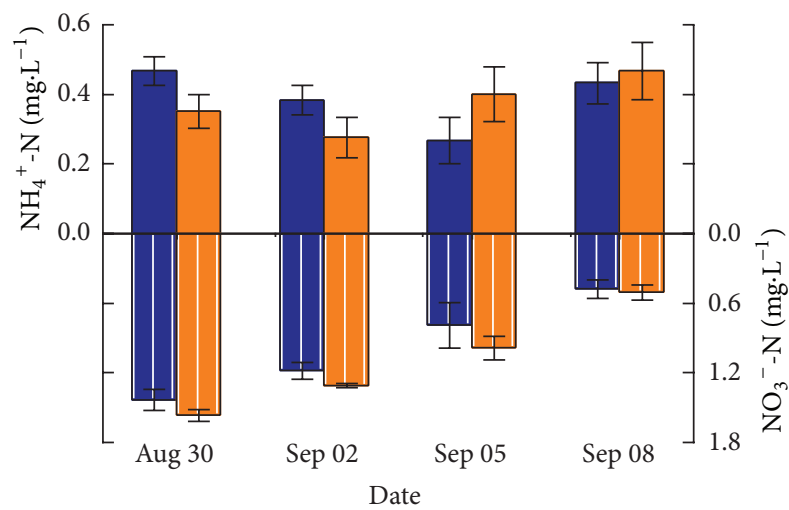

W5
$\square$ W6

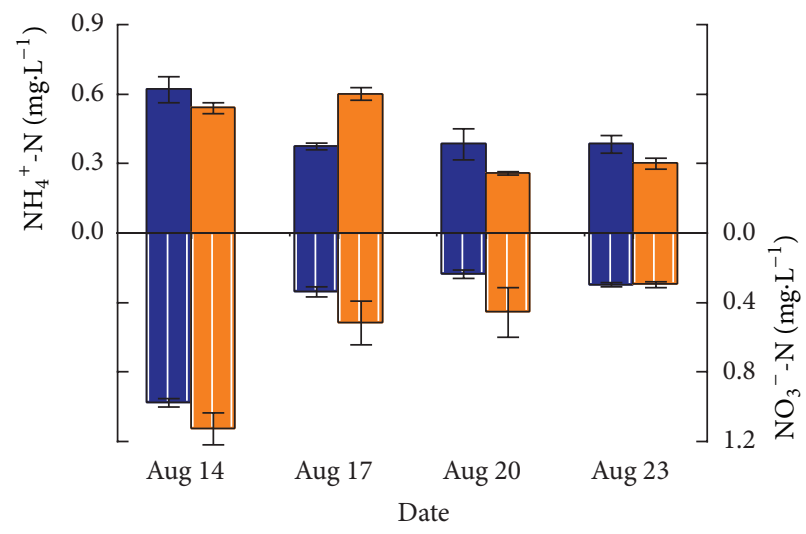

(b)

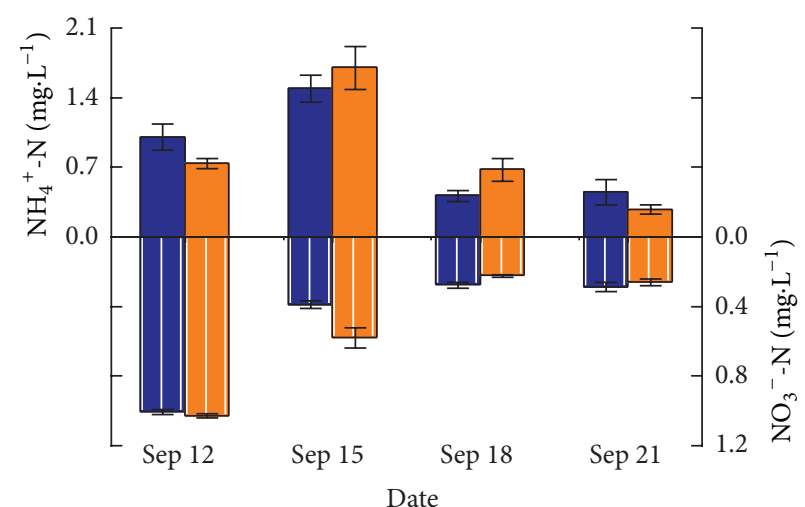

(d)

FIGURE 2: Dynamic changes of $\mathrm{NH}_{4}{ }^{+}-\mathrm{N}$ and $\mathrm{NO}_{3}{ }^{-}-\mathrm{N}$ concentration in surface water. (a) Tillering stage. (b) Jointing-booting stage. (c) Heading-flowering stage. (d) Milking stage.

fertilizer (date: June 28, type: compound fertilizer, amount: $1200 \mathrm{~kg} / \mathrm{ha}$ ), tillering fertilizer (date: July 5, type: urea, amount: $130 \mathrm{~kg} / \mathrm{ha}$ ), and panicle fertilizer (date: August 6, type: urea, amount: $130 \mathrm{~kg} / \mathrm{ha}$ ), in this specific order. All other recommended cultivated practices for achieving maximum grain yield were followed.

2.3. Sampling and Data Analysis. Water samples were collected four times during flooding period at each stage, according to the following sequence which was the 1st, 4th, 7 th, and 10th day after being controlled. Surface water was collected by $50 \mathrm{ml}$ syringe and saved in polyethylene bottle, without disturbing soil and selecting randomly. Water samples were analyzed for ammonium nitrogen $\left(\mathrm{NH}_{4}{ }^{+}-\mathrm{N}\right)$ and nitrate nitrogen $\left(\mathrm{NO}_{3}{ }^{-}-\mathrm{N}\right)$ using a Shimadzu UV-2800 spectrophotometer. $\mathrm{NH}_{4}{ }^{+}-\mathrm{N}$ was determined by Nessler's reagent colorimetric method (GB7479-87). $\mathrm{NO}_{3}{ }^{-}-\mathrm{N}$ was determined by the ultraviolet spectrophotometry method $(\mathrm{HJ} / \mathrm{T}$ 346-2007).
The $\mathrm{N}$ losses via subsurface drainage were calculated by multiplying the $\mathrm{N}$ concentrations (both $\mathrm{NH}_{4}{ }^{+}-\mathrm{N}$ and $\mathrm{NO}_{3}{ }^{-}-$ $\mathrm{N}$ ) in the water samples and the volume of the drainage, and surface water $\mathrm{N}$ loads were calculated using $\mathrm{N}$ concentration and surface water volume also. One-way ANOVA was used to detect the effect from $\mathrm{N}$ concentration to $\mathrm{N}$ leaching. Statistical analyses of the data were performed using SPSS.

\section{Results}

\subsection{Dynamic Changes of $\mathrm{NH}_{4}^{+}-\mathrm{N}^{+}$and $\mathrm{NO}_{3}{ }^{-}-\mathrm{N}$ Concentration}

3.1.1. $\mathrm{NH}_{4}{ }^{+}-\mathrm{N}$ and $\mathrm{NO}_{3}{ }^{-}-\mathrm{N}$ in Surface Water. Figure 2 shows the dynamic changes of $\mathrm{NH}_{4}{ }^{+}-\mathrm{N}$ and $\mathrm{NO}_{3}{ }^{-}-\mathrm{N}$ concentration in surface water of paddy field under controlled drainage. Overall, a declining tendency was observed in the concentration levels of $\mathrm{NH}_{4}{ }^{+}-\mathrm{N}$ and $\mathrm{NO}_{3}{ }^{-}-\mathrm{N}$, except that the $\mathrm{NO}_{3}{ }^{-}$$\mathrm{N}$ concentration was increased during the tillering stage, whereas $\mathrm{NH}_{4}{ }^{+}-\mathrm{N}$ was increased later in the heading and 

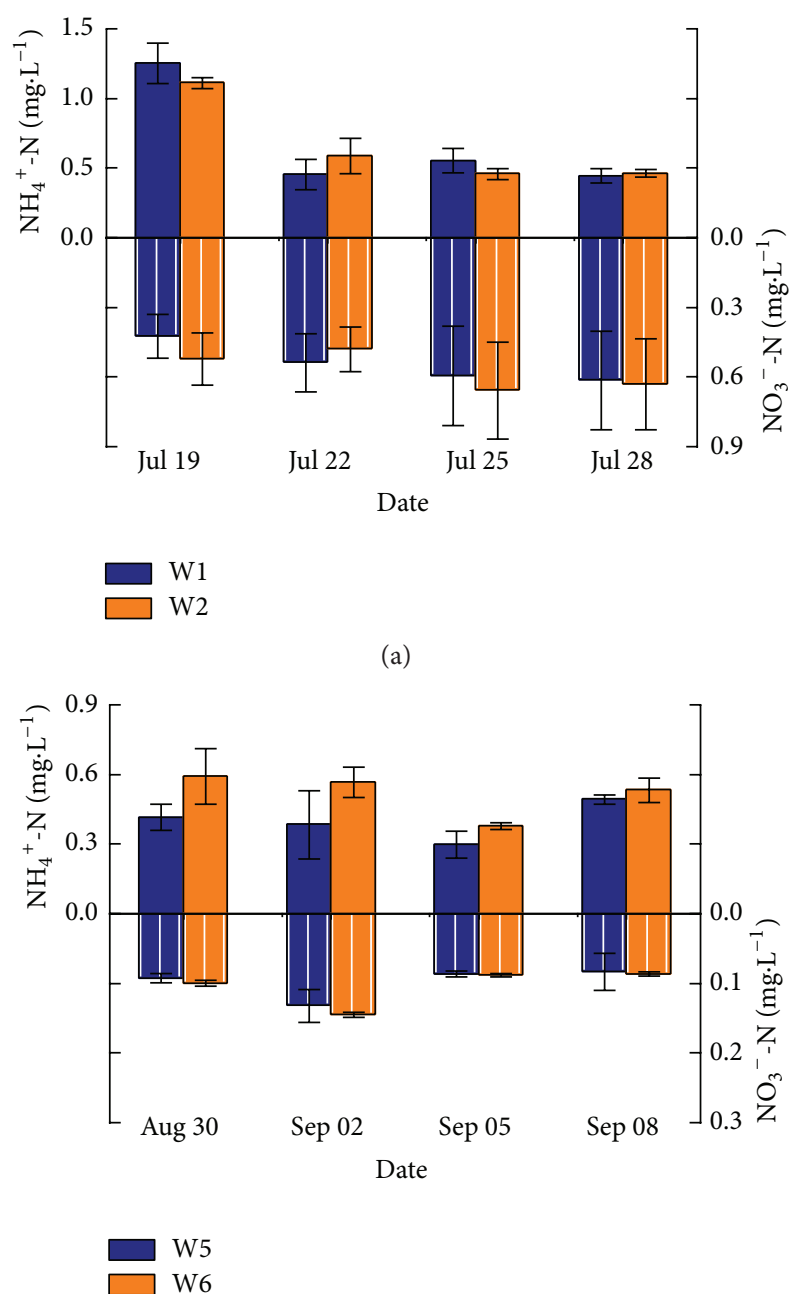

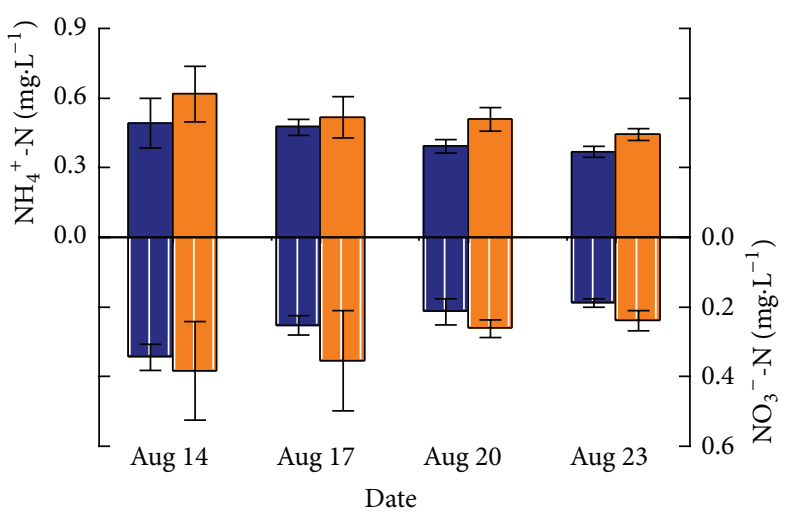

(b)

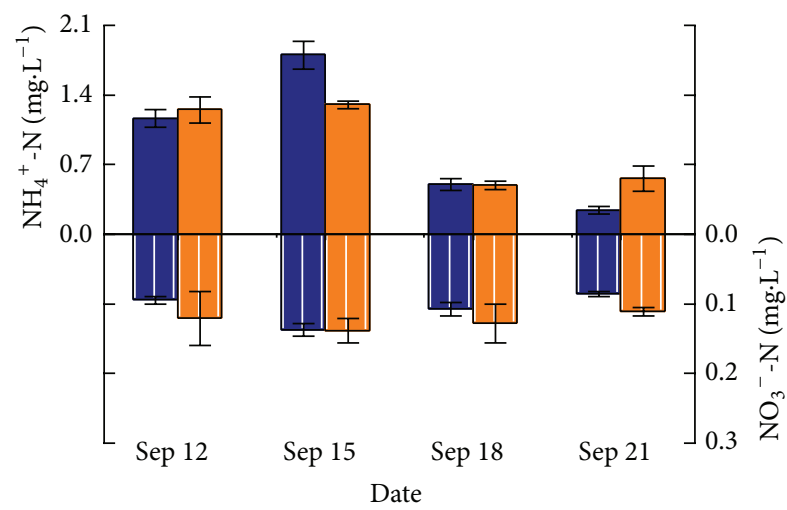

$\square 7$
$\square$ W8

(c)

(d)

Figure 3: Dynamic changes of $\mathrm{NH}_{4}{ }^{+}-\mathrm{N}$ and $\mathrm{NO}_{3}{ }^{-}-\mathrm{N}$ concentration in subsurface water. (a) Tillering stage. (b) Jointing-booting stage. (c) Heading-flowering stage. (d) Milking stage.

flowering stage (September 5-8) and early in the milky stage (September 12-15).

$\mathrm{N}$ concentration was relatively higher on the first day after waterlogging. On the 10th day, the $\mathrm{NH}_{4}{ }^{+}-\mathrm{N}$ concentration for $\mathrm{W} 1, \mathrm{~W} 2, \mathrm{~W} 3, \mathrm{~W} 4, \mathrm{~W} 7$, and $\mathrm{W} 8$ was reduced to $68.3 \%, 67.4 \%$, $38.2 \%, 44.4 \%, 55.0 \%$, and $62.7 \%$, respectively. The $\mathrm{NO}_{3}{ }^{-}$ $\mathrm{N}$ concentration for $\mathrm{W} 3, \mathrm{~W} 4, \mathrm{~W} 5, \mathrm{~W} 6, \mathrm{~W} 7$, and $\mathrm{W} 8$ was reduced to $69.4 \%, 73.7 \%, 66.7 \%, 67.6 \%, 71.3 \%$, and $74.6 \%$, respectively.

3.1.2. $\mathrm{NH}_{4}{ }^{+}-\mathrm{N}$ and $\mathrm{NO}_{3}{ }^{-}-\mathrm{N}$ in Subsurface Water. Figure 3 presents the dynamic changes in $\mathrm{NH}_{4}{ }^{+}-\mathrm{N}$ and $\mathrm{NO}_{3}{ }^{-}-\mathrm{N}$ concentration in subsurface water of paddy field under controlled drainage. The trend of subsurface $\mathrm{NH}_{4}{ }^{+}-\mathrm{N}$ concentration variety corresponded with surface water concentration. Compared with the concentration on the first day after paddy field waterlogging, the $\mathrm{NH}_{4}{ }^{+}-\mathrm{N}$ concentration on the 10th day for $\mathrm{W} 1, \mathrm{~W} 2, \mathrm{~W} 3, \mathrm{~W} 4, \mathrm{~W} 7$, and $\mathrm{W} 8$ was reduced to $64.6 \%$, $58.4 \%, 25.4 \%, 28.4 \%, 79.4 \%$, and $55.4 \%$, respectively.
A remarkable downtrend of $\mathrm{NO}_{3}{ }^{-}-\mathrm{N}$ concentration was observed at the jointing and booting stage. The $\mathrm{NO}_{3}{ }^{-}-\mathrm{N}$ concentration on the 10th day for W3 and W4 was reduced to $45.5 \%$ and $37.4 \%$, respectively, compared with that on the first day. $\mathrm{NO}_{3}{ }^{-}-\mathrm{N}$ concentration was relatively higher at the tillering stage, mainly because of nitrification by residual $\mathrm{N}$ in soil. Meanwhile, the change in $\mathrm{NO}_{3}{ }^{-} \mathrm{N}$ concentration was smaller in other stages.

3.2. Effect from Drainage Intensity to $N$ Leaching. The amount of paddy $\mathrm{N}$ leaching during the control period is shown in Table 3. The amount of $\mathrm{N}$ leaching under $4 \mathrm{~mm} / \mathrm{d}$ leakage intensity was remarkable about two times larger than that under the $2 \mathrm{~mm} / \mathrm{d}$ treatment. The highest amount of $\mathrm{NH}_{4}{ }^{+}$$\mathrm{N}$ and $\mathrm{NO}_{3}{ }^{-}-\mathrm{N}$ leaching was observed at the milking and tillering stages, respectively.

Results of ANOVA for $\mathrm{N}$ concentration through leaching under two leakage intensities are shown in Table 4. All the Sig values $(p)$ were larger than 0.05 . Results show that the difference between the two conditions was not significant. 
TABLE 3: N leaching amount of controlled drainage paddy field under two leakage intensity conditions.

\begin{tabular}{|c|c|c|c|c|c|c|c|c|}
\hline Growth stage & Tille & stage & Jointir & ting stage & Headi & ering stage & Milk & stage \\
\hline Leakage intensity & $2 \mathrm{~mm} / \mathrm{d}$ & $4 \mathrm{~mm} / \mathrm{d}$ & $2 \mathrm{~mm} / \mathrm{d}$ & $4 \mathrm{~mm} / \mathrm{d}$ & $2 \mathrm{~mm} / \mathrm{d}$ & $4 \mathrm{~mm} / \mathrm{d}$ & $2 \mathrm{~mm} / \mathrm{d}$ & $4 \mathrm{~mm} / \mathrm{d}$ \\
\hline $\mathrm{NH}_{4}{ }^{+}-\mathrm{N}\left(\mathrm{g} \cdot \mathrm{ha}^{-2}\right)$ & 134.93 & 261.84 & 86.25 & 208.33 & 79.35 & 206.97 & 185.13 & 359.58 \\
\hline $\mathrm{NO}_{3}{ }^{-}-\mathrm{N}\left(\mathrm{g} \cdot \mathrm{ha}^{-2}\right)$ & 108.6 & 229.16 & 49.96 & 124.16 & 19.76 & 42.05 & 21.27 & 49.93 \\
\hline
\end{tabular}

TABLE 4: ANOVA results for $\mathrm{N}$ concentration through leaching under two leakage intensity conditions.

\begin{tabular}{lcccccccc}
\hline \multirow{2}{*}{ Factors } & \multicolumn{2}{c}{ Tillering stage } & \multicolumn{3}{c}{ Jointing-booting stage } & \multicolumn{2}{c}{ Heading-flowering stage } & \multicolumn{2}{c}{ Milking stage } \\
& $F$ & Sig & $F$ & Sig & $F$ & Sig & $F$ & Sig \\
\hline $\mathrm{NH}_{4}{ }^{+}-\mathrm{N}$ & 0.007 & 0.938 & 3.573 & 0.108 & 3.703 & 0.103 & 0.004 & 0.950 \\
$\mathrm{NO}_{3}{ }^{-}-\mathrm{N}$ & 0.246 & 0.638 & 1.533 & 0.262 & 0.127 & 0.734 & 2.118 \\
\hline
\end{tabular}

3.3. Effect of Pollution Reduction. Surface water $\mathrm{N}$ loads and emission reduction of $\mathrm{N}$ under different flooding times are shown in Figures 4 and 5. N loads in surface paddy water declined along with the persistence of waterlogging duration. Compared with traditional drainage (drainage immediately after waterlogging), PFCD (10 d) reduced $\mathrm{N}$ loss in surface water by $95.6 \%, 78.7 \%, 59.6 \%$, and $87.4 \%$ at each of the four stages, in this particular order.

\section{Discussion}

The results indicated that $\mathrm{N}$ concentration in surface water decreased effectively when proper subsurface drainage rate in the paddy field is maintained in the waterlogging condition. This condition is caused by several processes. The reasons for the decline in $\mathrm{NH}_{4}{ }^{+}-\mathrm{N}$ concentration include volatilization, nitrification, soil adsorption, crop absorption, and migration into depth. Meanwhile, the reasons for the decline in $\mathrm{NO}_{3}{ }^{-}-\mathrm{N}$ concentration include denitrification, crop absorption, leaching loss, and migration into depth [30-34]. Nitrification and denitrification are two important mechanisms of nitrogen transform and $\mathrm{N}_{2} \mathrm{O}$ emissions from fields. Many factors regulate these processes, particularly soil water content and temperature, microorganism types, and $\mathrm{PH}$, and so on. Subsurface environment affects the activity of soil bacteria significantly. The mechanisms of temperature and soil water regime effects should be studied specifically.

$\mathrm{N}$ concentration was relatively higher on the first day after waterlogging. This phenomenon was caused by $\mathrm{N}$ released from surface soil, which is disturbed by water-drop splash from irrigation or rainfall. $\mathrm{NH}_{4}{ }^{+}-\mathrm{N}$ concentration was later increased at the heading and flowering stage (September 58 ) and in the early days at the milky stage (September 12-15). This phenomenon can explain the organic nitrogen released from the paddy field, which was accelerated by scorching weather. $\mathrm{NO}_{3}{ }^{-}-\mathrm{N}$ concentration was lower at the tillering stage, where the urea may still be in a hydrolytic status, and a cumulative process occurs for $\mathrm{NH}_{4}{ }^{+}-\mathrm{N}$ to nitrify into $\mathrm{NO}_{3}{ }^{-}$N.

Generally, $\mathrm{NO}_{3}{ }^{-}-\mathrm{N}$ was relatively stable and was found to migrate into aquifer heavily. $\mathrm{NH}_{4}{ }^{+}-\mathrm{N}$ was difficult to remove from underground and its conversion process into soil was complicated. The underground environment in the paddy field under controlled drainage was highly complex because it involved the effects of soil, moisture, crop, microorganism, and fertilizer. Therefore, the mechanism of $\mathrm{N}$ migration and transformation requires further research.

Results of ANOVA for subsurface water N concentration showed that the difference between the two drainage intensities was not significant. Wesström et al. [35] compared the conventional drainage system and controlled drainage strategies through a field experiment in Southern Sweden, and the experiment results showed that the $\mathrm{N}$ and $\mathrm{P}$ losses in controlled drainage were lower than those in conventional drainage, but $\mathrm{N}$ and $\mathrm{P}$ concentrations in subsurface drainage water were revealed to have no significant differences between the two drainage systems. Such results were similar to ours, although the conditions we compared were both under a controlled drainage system. This suggests that the $\mathrm{N}$ concentrations were similar under two leakage conditions. $\mathrm{N}$ loss through drainage increases as runoff volume increases. Furthermore, we consider drainage water volume as the main factor that affects $\mathrm{N}$ leaching amount.

As mentioned, a mass of $\mathrm{N}$ wound was released from surface soil, which was disturbed by irrigation or rainfall on the first day after waterlogging. Thus, we should not discharge the surface water immediately after paddy flooding. In our tests, the loads of $\mathrm{N}$ losses on the fourth day after waterlogging were increased at the jointing-booting and milking stages. Surface drainage should be avoided in these conditions as well.

On the contrary, several disadvantages are caused by prolonged waterlogging. Waterlogging duration has remarkable effects on crop yield. For instance, when the surface water level is too high in the tillering stage, it will cause the number of tillers to reduce and lead directly to reducing the rice yield in the late stage. So, paddy water should be drained at an appropriate time. Rice plant manifests root hypoxia when it lives in the field without leakage or without being in deep water for a long time. This condition goes against the physiological metabolism of the rice plant and therefore disrupts photosynthesis, eventually causing plant growth retardation and yield reduction. These adverse effects can be reduced by enhancing field leakage, which can increase soil ventilation volume.

Paddy field controlled drainage can effectively save irrigation water and decrease nitrogen pollution emission. However, many issues require further study, such as how rice yield losses can be minimized on the basis of water saving 


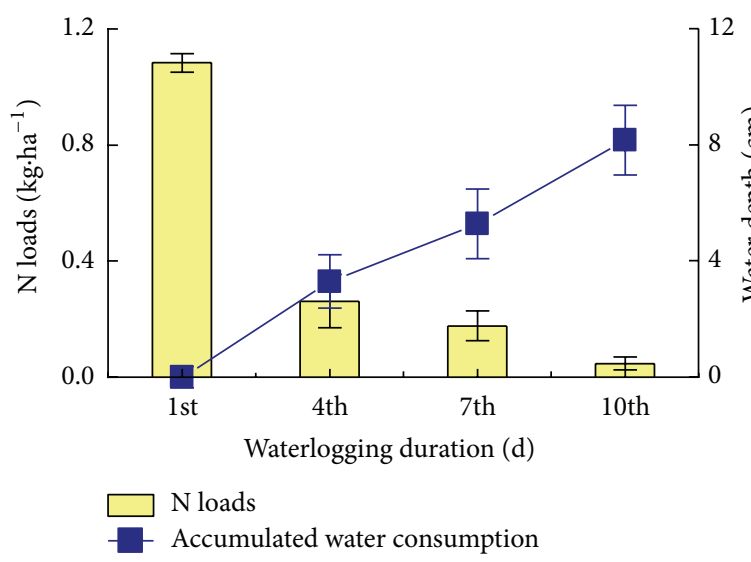

(a)

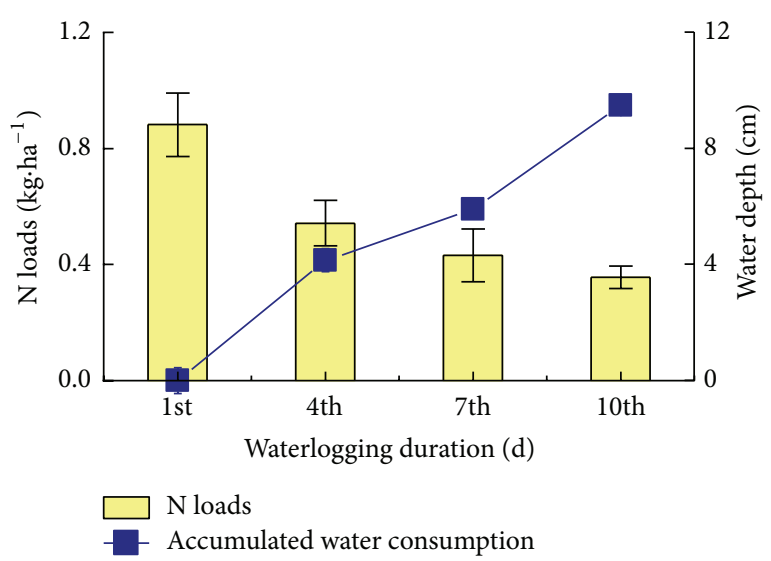

(c)

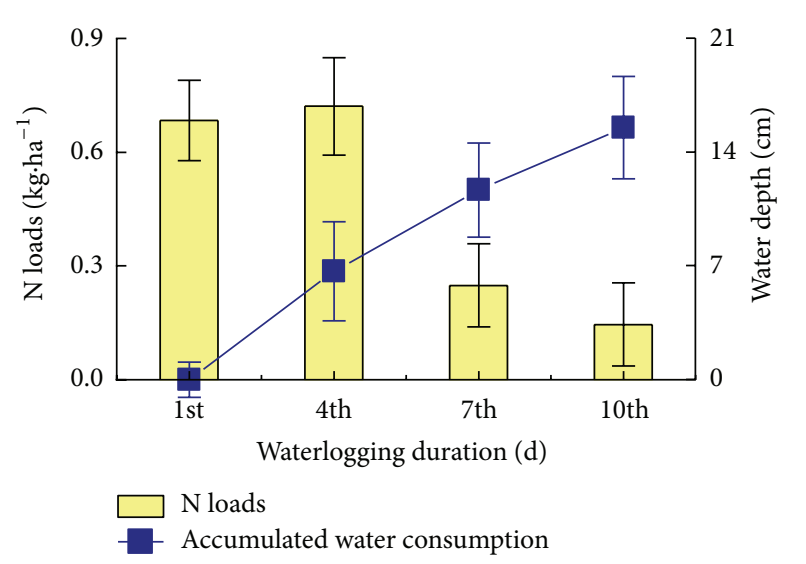

(b)

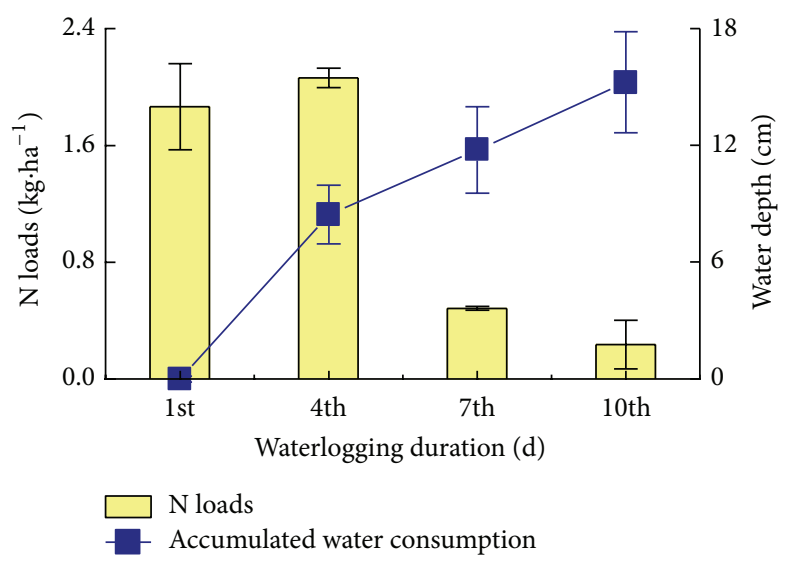

(d)

FIGURE 4: Loads of $\mathrm{N}$ in surface water and accumulated water consumption. (a) Tillering stage. (b) Jointing-booting stage. (c) Headingflowering stage. (d) Milking stage. The accumulated water consumption was measured by water decrease depth.

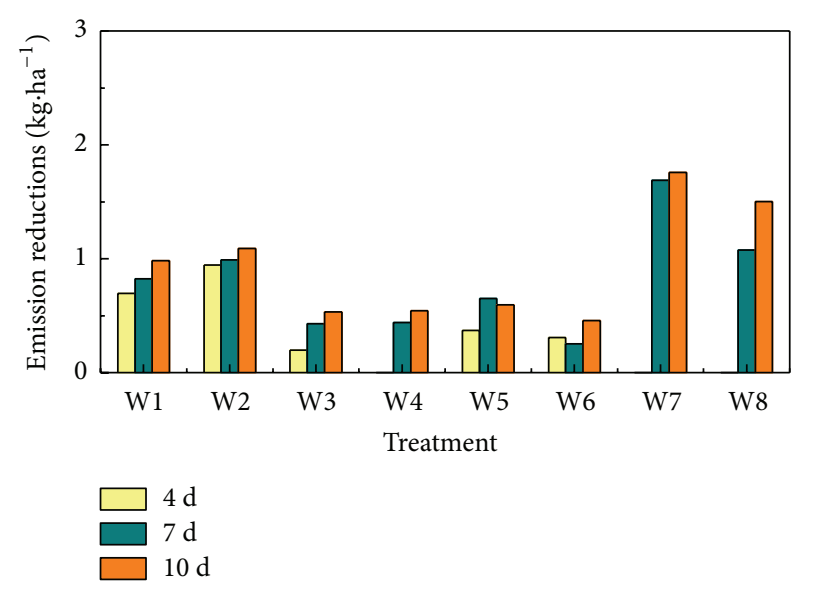

FIGURE 5: N emission reductions of PFCD treatments.

and pollution reduction. Such a problem must be assessed comprehensively from the perspectives of surface water depth, flooding stage and time of duration, leakage intensity, and other factors. More tests need to be carried out in the future to provide a basis for decision-making. We can deter- mine the optimal drainage time through the multiobjective analysis method.

\section{Conclusions}

By analyzing $\mathrm{N}$ concentration and calculating the amount of $\mathrm{N}$ leaching and loads of $\mathrm{N}$ losses, we can summarize the main conclusions of this experimental study as follows:

(1) The $\mathrm{NH}_{4}{ }^{+}-\mathrm{N}$ and $\mathrm{NO}_{3}{ }^{-}-\mathrm{N}$ concentrations in paddy water declined along with the prolongation of waterlogging duration. Surface water was found to have higher $\mathrm{N}$ concentration on the first day after paddy field waterlogging at each stage, and loads of $\mathrm{N}$ losses increased on the fourth day at the jointing-booting and milking stages. Thus, surface drainage should be avoided in these two conditions.

(2) The amount of $\mathrm{N}$ leaching under $4 \mathrm{~mm} / \mathrm{d}$ leakage intensity was approximately two times larger than that under the $2 \mathrm{~mm} / \mathrm{d}$ treatment. Results of ANOVA for $\mathrm{N}$ concentration through leaching under the two leakage intensities showed that the difference between such intensity levels was not significant. Therefore, the 
main factor that affects $\mathrm{N}$ leaching amount is seepage water volume.

(3) Loads of $\mathrm{N}$ losses in surface paddy water declined with the continuation of waterlogging duration. Compared with traditional drainage, controlled drainage reduced $\mathrm{N}$ loss in surface water by $95.6 \%$, $78.7 \%, 59.6 \%$, and $87.4 \%$ at each of the four stages.

\section{Competing Interests}

The authors declare that they have no competing interests.

\section{Acknowledgments}

This work was financially supported by the National Natural Science Foundation of China (Grant no. 51479063), the Ministry of Water Resources' Special Funds for Scientific Research on Public Causes (Grant nos. 201401083 and 201401058), and the Scientific Research Foundation of NHRI (Grant nos. Y113007 and Y113008).

\section{References}

[1] W. Shao, "Effectiveness of water protection policy in China: a case study of Jiaxing," Science of the Total Environment, vol. 408, no. 4, pp. 690-701, 2010.

[2] E. D. Ongley, Z. Xiaolan, and Y. Tao, "Current status of agricultural and rural non-point source pollution assessment in China," Environmental Pollution, vol. 158, no. 5, pp. 1159-1168, 2010.

[3] H. Hu and G. Huang, "Monitoring of non-point source pollutions from an agriculture watershed in South China," Water, vol. 6, no. 12, pp. 3828-3840, 2014.

[4] H. Y. Guo, X. R. Wang, and J. G. Zhu, "Quantification and index of non-point source pollution in Taihu Lake region with GIS," Environmental Geochemistry and Health, vol. 26, no. 2, pp. 147156, 2004.

[5] L. Gao, J. M. Zhou, H. Yang, and J. Chen, "Phosphorus fractions in sediment profiles and their potential contributions to eutrophication in Dianchi Lake," Environmental Geology, vol. 48, no. 7, pp. 835-844, 2005.

[6] C. Le, Y. Zha, Y. Li, D. Sun, H. Lu, and B. Yin, "Eutrophication of lake waters in China: cost, causes, and control," Environmental Management, vol. 45, no. 4, pp. 662-668, 2010.

[7] J. Qiao, L. Yang, T. Yan, F. Xue, and D. Zhao, "Nitrogen fertilizer reduction in rice production for two consecutive years in the Taihu Lake area," Agriculture, Ecosystems and Environment, vol. 146, no. 1, pp. 103-112, 2012.

[8] J. E. Ayars, E. W. Christen, and J. W. Hornbuckle, "Controlled drainage for improved water management in arid regions irrigated agriculture," Agricultural Water Management, vol. 86, no. 1-2, pp. 128-139, 2006.

[9] R. W. Skaggs, N. R. Fausey, and R. O. Evans, "Drainage water management," Journal of Soil and Water Conservation, vol. 67, no. 6, pp. 167A-172A, 2012.

[10] S. Peng, Y. Luo, J. Xu, S. Khan, X. Jiao, and W. Wang, "Integrated irrigation and drainage practices to enhance water productivity and reduce pollution in a rice production system," Irrigation and Drainage, vol. 61, no. 3, pp. 285-293, 2012.
[11] S. E. Yu, Z. M. Miao, W. G. Xing, G. C. Shao, and Y. X. Jiang, "Research advance on irrigation-drainage for rice by using field water level as regulation index," Journal of Irrigation and Drainage, vol. 29, no. 2, pp. 134-136, 2010.

[12] B. Lu, S. Q. Wu, S. E. Yu et al., "Changes of N concentration and effects of pollution reducing and water saving in paddy field under controlled drainage," in Proceedings of the 35th IAHR World Congress, pp. 3297-3303, Chengdu, China, September 2013.

[13] H. Y. F. Ng, C. S. Tan, C. F. Drury, and J. D. Gaynor, "Controlled drainage and subirrigation influences tile nitrate loss and corn yields in a sandy loam soil in Southwestern Ontario," Agriculture, Ecosystems and Environment, vol. 90, no. 1, pp. 81-88, 2002.

[14] J. W. Gilliam, R. W. Skaggs, and S. B. Weed, "Drainage control to diminish nitrate loss from agricultural fields," Journal of Environmental Quality, vol. 8, no. 1, pp. 137-142, 1979.

[15] R. O. Evans, J. W. Gilliam, and R. W. Skaggs, "Effects of agricultural water table management on drainage quality," Tech. Rep. 237, Water Resources Research Institute of the University of North Carolina, Raleigh, NC, USA, 1989.

[16] M. A. S. Wahba, M. El-Ganainy, M. S. Abdel-Dayem, A. T. E. F. Gobran, and H. Kandil, "Controlled drainage effects on water quality under semi-arid conditions in the Western Delta of Egypt," Irrigation and Drainage, vol. 50, no. 4, pp. 295-308, 2001.

[17] G. Bonaiti and M. Borin, "Efficiency of controlled drainage and subirrigation in reducing nitrogen losses from agricultural fields," Agricultural Water Management, vol. 98, no. 2, pp. 343352, 2010.

[18] C. F. Drury, C. S. Tan, J. D. Gaynor, T. O. Oloya, and T. W. Welacky, "Influence of controlled drainage-subirrigation on surface and tile drainage nitrate loss," Journal of Environmental Quality, vol. 25, no. 2, pp. 317-324, 1996.

[19] I. Wesström, I. Messing, H. Linnér, and J. Lindström, "Controlled drainage-effects on drain outflow and water quality," Agricultural Water Management, vol. 47, no. 2, pp. 85-100, 2001.

[20] W. Luo, G. R. Sands, M. Youssef, J. S. Strock, I. Song, and D. Canelon, "Modeling the impact of alternative drainage practices in the northern Corn-belt with DRAINMOD-NII," Agricultural Water Management, vol. 97, no. 3, pp. 389-398, 2010.

[21] Y. F. Zhang, W. Z. Zhang, and R. K. Shen, "The study of the transport, transformation and losses of nitrogen in drained agricultural lands," Journal of Hydrodynamics, Series A, vol. 11, no. 3, pp. 251-260, 1996 (Chinese).

[22] W. Luo, Z.-H. Jia, S.-X. Fang, and L. Wang, "Effect of drainage control on salt and water balance in rice field," Journal of Hydraulic Engineering, vol. 37, no. 5, pp. 608-618, 2006 (Chinese).

[23] Z. H. Jia, W. Luo, S. Fang, N. Wang, and L. Wang, "Evaluating current drainage practices and feasibility of controlled drainage in the YinNan Irrigation District, China," Agricultural Water Management, vol. 84, no. 1-2, pp. 20-26, 2006.

[24] M.-H. Xiao, S.-E. Yu, G. Cheng, and D.-L. Shao, “Technical standards of irrigation and drainage management in paddy field of water-saving and pollution-reduction with high yield," Journal of Food, Agriculture \& Environment, vol. 10, no. 2, pp. 1005-1011, 2012.

[25] M.-H. Xiao, S.-E. Yu, Y.-Y. Wang, and R. Huang, "Nitrogen and phosphorus changes and optimal drainage time of flooded paddy field based on environmental factors," Water Science and Engineering, vol. 6, no. 2, pp. 164-177, 2013. 
[26] S. E. Yu, Research on Irrigation and Drainage for Rice by Using Field Water Table as Regulation Index, Hohai University, 2008 (Chinese).

[27] G.-C. Shao, S. Deng, N. Liu, S.-E. Yu, M.-H. Wang, and D.-L. She, "Effects of controlled irrigation and drainage on growth, grain yield and water use in paddy rice," European Journal of Agronomy, vol. 53, pp. 1-9, 2014.

[28] G. Shao, J. Cui, S. E. Yu et al., "Impacts of controlled irrigation and drainage on the yield and physiological attributes of rice," Agricultural Water Management, vol. 149, pp. 156-165, 2015.

[29] S. Z. Peng, S. S. Li, G. L. Xu, and Z. Wu, "New water consumption pattern of rice under water-saving irrigation," Irrigation and Drainage Systems, vol. 8, no. 2, pp. 97-108, 1994.

[30] T. M. Addiscott and D. S. Powlson, "Partitioning losses of nitrogen fertilizer between leaching and denitrification," The Journal of Agricultural Science, vol. 118, no. 1, pp. 101-107, 1992.

[31] B. A. Kliewer and J. W. Gilliam, "Water table management effects on denitrification and nitrous oxide evolution," Soil Science Society of America Journal, vol. 59, no. 6, pp. 1694-1701, 1995.

[32] M. Paasonen-Kivekäs, T. Karvonen, P. Vakkilainen, N. Sepahi, J. Kleemola, and M. Teittinen, "Field studies on controlled drainage and recycling irrigation drainage for reduction of nutrient loading from arable land," Water Science and Technology, vol. 33, no. 4-5, pp. 333-339, 1996.

[33] S. Y. Feng and Y. Q. Zheng, "Transformations and losses of the agricultural nitrogen and its effects on water quality," AgroEnvironmental Protection, vol. 6, pp. 277-280, 1996 (Chinese).

[34] C. Wang, "Experimental study of nitrogen transportand transformation in soils," Advances in Water Science, vol. 2, pp. 176182, 1997 (Chinese).

[35] I. Wesström, A. Joel, and I. Messing, "Controlled drainage and subirrigation-a water management option to reduce non-point source pollution from agricultural land," Agriculture, Ecosystems and Environment, vol. 198, pp. 74-82, 2014. 

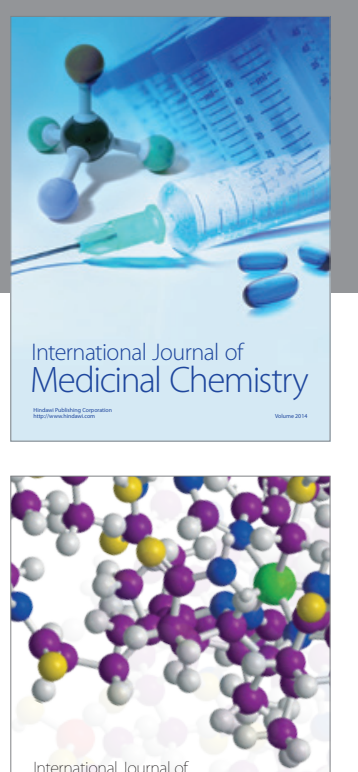

Carbohydrate Chemistry

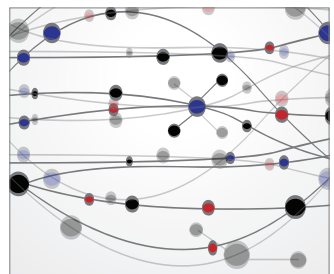

The Scientific World Journal
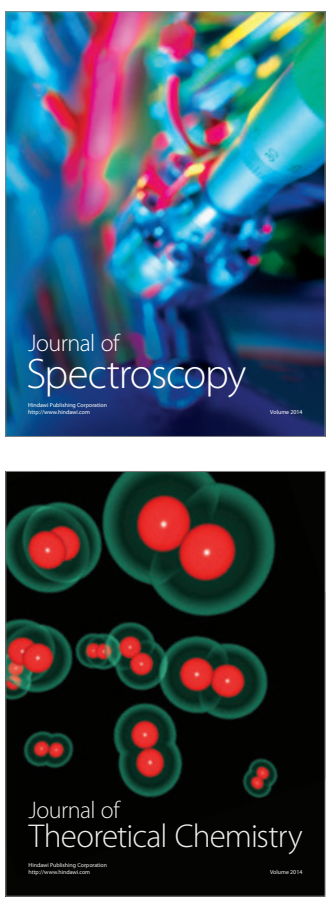
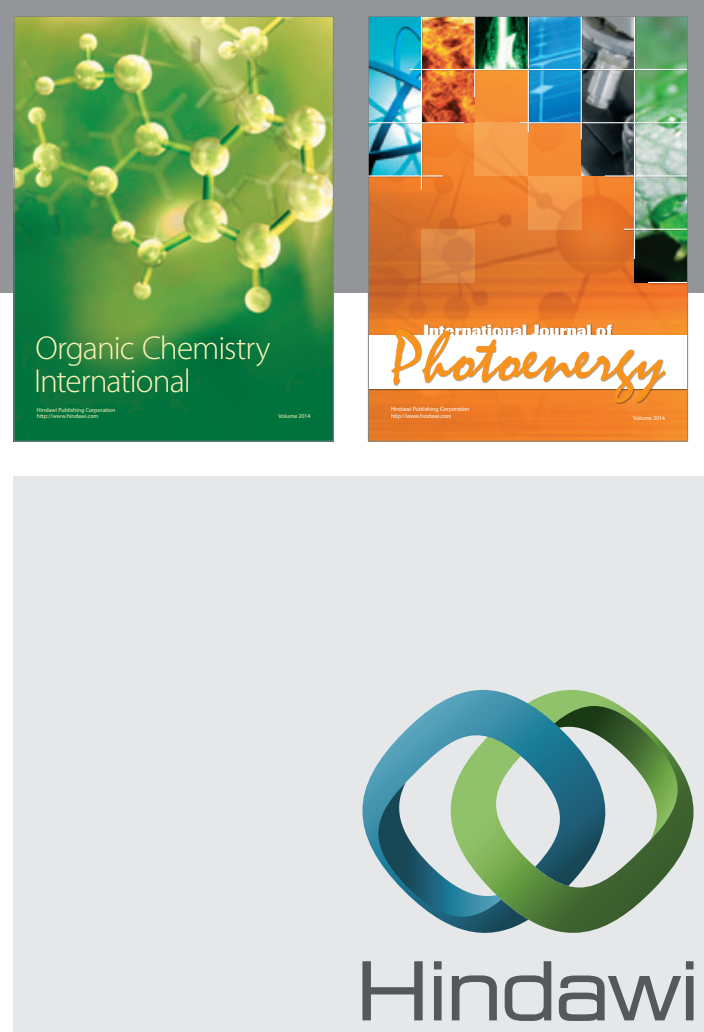

Submit your manuscripts at

http://www.hindawi.com

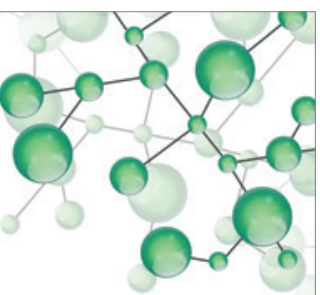

International Journal of

Inorganic Chemistry

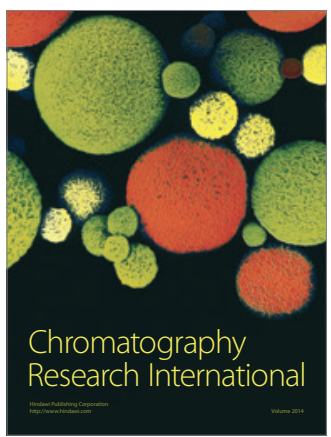

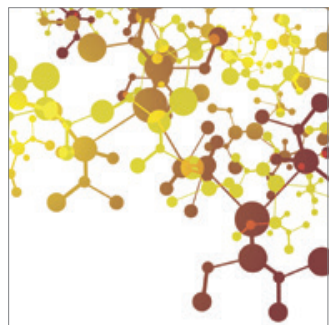

Applied Chemistry
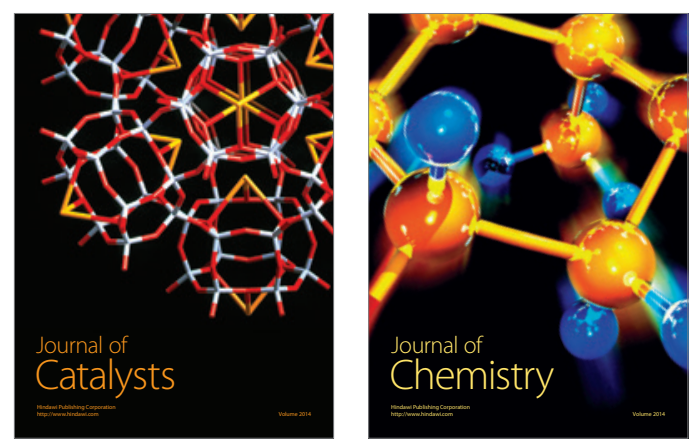
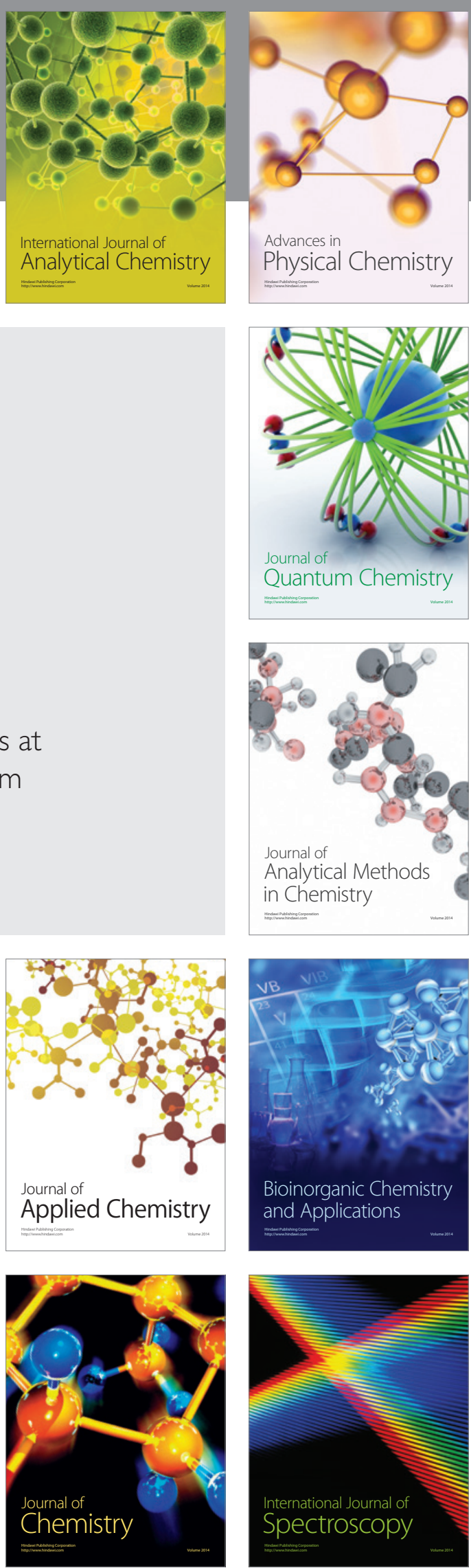